\title{
Effect of blood on the assay of 6-phosphogluconate dehydrogenase in vaginal fluid
}

\author{
D. F. GIBBS \\ From the Obstetric Unit Research Laboratories, University College Hospital Medical School, London
}

SYNOPSIS The effect of blood in vaginal fluid on the assay of 6-phosphogluconate dehydrogenase has been studied. Alternative assay procedures have been investigated to overcome these effects.

A study of the activity of 6-phosphogluconate dehydrogenase (Enzyme Commission No. 1.1.1.44) in the vaginal fluid of large numbers of women has been carried out to investigate whether the assay of this enzyme would be suitable for widespread application as a screening procedure for early gynaecological cancer (Bonham and Gibbs, 1962; Labrum, 1965; Cameron, 1964; Nerdrum, 1964; Boyd, Gibbs, Labrum, and Philps, 1967).

Many specimens of vaginal fluid contain apprecible amounts of blood, although specimens are not taken during menstruation. This is particularly so with specimens from patients with carcinoma of the cervix. During the course of these studies we have observed that blood interferes with the assay used for 6-phosphogluconate dehydrogenase which is based on a final measurement of the extinction at $340 \mathrm{~m} \mu$ due to $\mathrm{NADPH}_{2}$.

Lowry, Passonneau, and Rock (1961) have reported that blood, even at very low concentrations, was capable of greatly accelerating $\mathrm{NADH}_{2}$ and $\mathrm{NADPH}_{2}$ oxidation at $p \mathrm{H}$ values from 8 to 12 . As the enzyme test described by Bonham and Gibbs (1962) takes place at $p \mathrm{H} \mathrm{9.0} \mathrm{considerable} \mathrm{reoxidation}$ of the nucleotide may well take place in this test system due to the presence of significant amounts of blood.

This paper deals with the investigation of this problem and describes a method of overcoming it by the addition of tryptophane and nicotinamide to the assay system to inhibit both enzymic and nonenzymic destruction of the nucleotides.

To overcome the difficulty caused by reoxidation of $\mathrm{NADPH}_{2}$ due to the presence of blood, the reduced nucleotide was coupled non-enzymically to cause a reduction of a blue dye (2.6 dichlorophenol indophenol). Thus the reduction can be measured by following the bleaching of the dye at $600 \mathrm{~m} \mu$.

Received for publication 30 June 1967.

\section{METHODS}

Vaginal fluid was collected from patients with carcinoma of the cervix in the manner described by Bonham and Gibbs (1962). This source of fluid was chosen to guarantee an active sample. The amount of blood present was determined by the following modification of the method of Meijer (1962).

Specimens of vaginal fluid were made up to $3 \mathrm{ml}$. with glass-distilled water and then homogenized using a Teflon pestle in a glass barrel. To $1 \mathrm{ml}$. of the homogenate $0.15 \mathrm{ml}$. of $0.14 \mathrm{M}$ ammonia solution was added and the volume made up to $3 \mathrm{ml}$. After standing for 10 minutes, the sample was centrifuged and the extinctions read at 580,605 , and $630 \mathrm{~m} \mu$.

Whole blood (obtained by venepuncture) from the same patient, $0.02 \mathrm{ml}$. plus $0.15 \mathrm{ml}$. of $0.14 \mathrm{M}$ ammonia solution, was made up to $3 \mathrm{ml}$. with glass-distilled water and the extinctions were read at 580 and $605 \mathrm{~m} \mu$.

The percentage blood in the specimens was calculated as follows:

$\%$ blood in specimen $=$

$$
\frac{\left(E_{580}-E_{605}\right)-\left(E_{605}-E_{630}\right) \text { sample }}{\left(E_{580}-E_{605}\right) \text { whole blood }} \times 2
$$

The values were expressed as a percentage of whole blood on the basis of a normal haematocrit value.

Blood determinations were performed on the vaginal fluids of 50 patients and were found to fall within the range 0 to $0.5 \%$.

When investigating the effect of blood on 6-phosphogluconate dehydrogenase activity, samples of vaginal fluid having no significant blood content were taken and the supernatant was prepared as previously described. Aliquots of whole blood obtained by venepuncture using lithium heparin as anticoagulant (lithium heparin was found to have no effect on the enzyme activity) were added to the supernatant and made up to a standard final volume with glass-distilled water. Controls were prepared using supernatant and water only. Similar aliquots of blood were taken with glass-distilled water to ascertain the enzyme activity contributed by the blood alone.

The assay of 6-phosphogluconate dehydrogenase activity, based on the original assay of Bonham and Gibbs (1962), was as follows: 


\section{System I}

$1.50 \mathrm{ml}$. glycyl glycine buffer $0.25 \mathrm{M} \mathrm{pH} 9.0$

$0.50 \mathrm{ml}$. 6-phosphogluconate $\mathrm{Mg}$. (6PG) $0.02 \mathrm{M}$

$0.50 \mathrm{ml}$. nicotinimide-adenine dinucleotide phos-

phate (NADP) $2 \mathrm{mg} . / \mathrm{ml}$.

$0.50 \mathrm{ml}$. supernatant

Total $3.00 \mathrm{ml}$.

Blanks $0.50 \mathrm{ml}$. water instead of $6 \mathrm{PG}$, otherwise as for test.

The reaction was started by the addition of the NADP to the system. The optical density change at $340 \mathrm{~m} \mu$ was recorded over the first five minutes at $25^{\circ} \mathrm{C}$.

Experiments using vaginal fluid with increasing blood concentrations showed that at very low blood levels the measured enzyme activity was slightly higher than in the absence of blood and then a rapid fall in measured activity was shown with increasing blood concentration (Fig. 1).

To overcome this difficulty the reduced nucleotide was coupled with 2.6 dichlorophenol indophenol in the presence of phenazonium methosulphate and the change in optical density was followed at $600 \mathrm{~m} \mu$.

System II

$1.20 \mathrm{ml}$. glycyl glycine buffer $0.25 \mathrm{M} p \mathrm{H} \mathrm{9.0}$

$0.50 \mathrm{ml}$. 6 PG Mg. $0.02 \mathrm{M}$

$0.50 \mathrm{ml}$. NADP $2 \mathrm{mg} . / \mathrm{ml}$.

$0.05 \mathrm{ml}$. phenazonium methosulphate $2 \mathrm{mg} . / \mathrm{ml}$.

$0.25 \mathrm{ml}$. dichlorophenol indophenol $2 \mathrm{mg} . / 10 \mathrm{ml}$.

$0.50 \mathrm{ml}$. supernatant

Total $3.00 \mathrm{ml}$.

Blanks $0.50 \mathrm{ml}$. water instead of $6 \mathrm{PG}$, otherwise as for test.

The reaction was started as before, but the optical density change was measured at $600 \mathrm{~m} \mu$ over the first three minutes at $25^{\circ} \mathrm{C}$.

In both systems the enzyme values in the presence of blood were the total activity corrected for the activity of blood alone. The units of activity were all expressed

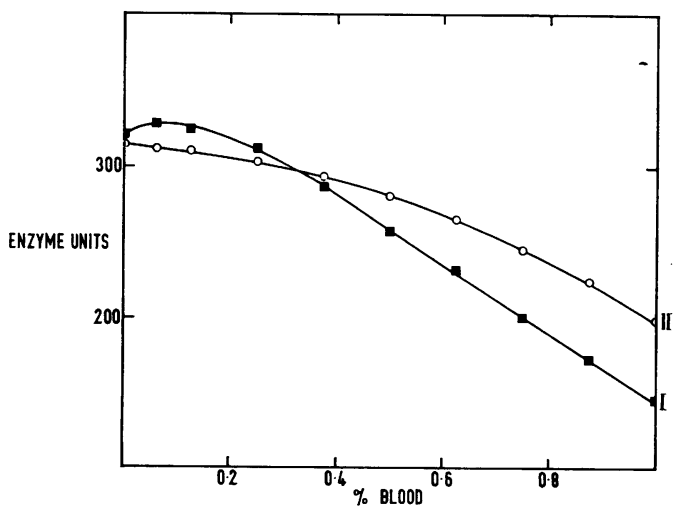

FIG. 1.

FIG. 1. Effect of blood concentration on vaginal fluid 6-phosphogluconate dehydrogenase using different assay systems. $\quad$ System I assay $\bigcirc-O$ System II assay

FIG. 2. Effect of blood concentration on vaginal fluid 6-phosphogluconate dehydrogenase with nicotinamide and tryptophane present. $\bigcirc-\bigcirc$ System II assay alone $10^{-2} \mathrm{M}$ and tryptophane $8.2 \times 10^{-4} \mathrm{M}$ as International Units $\times 10^{-2}$ as described in the International Union of Biochemistry Report of the Commission on Enzymes (1961). The relationship between the optical density readings obtained from the two systems was calculated from the following formula:-

$1 \mu$ mole $\mathrm{NADPH}_{2}$ produced $=$ fall of $\mathrm{OD} 600 \mathrm{~m} \mu$ of $0.5395 / \mathrm{min} . / 3 \mathrm{ml}$.

All assays were performed using a Unicam SP 800 double-beam recording spectrophotometer and the reagents were all supplied by Griffin and George Ltd.

\section{RESULTS}

Under the system II assay conditions the initial activation at low blood concentration was hardly apparent and the inhibition at the higher blood concentration was much less marked (Fig. 1).

It was felt that the apparent inhibition might in some part be due to the presence of nucleotidases.

The effect of adding nicotinamide and tryptophane to the assay system to overcome this problem was investigated (Fig. 2). Both the nicotinamide and the tryptophane were added dissolved in the NADP solution.

Initially the final nicotinamide concentration was $6.6 \times 10^{-2} \mathrm{M}$. (25 mg. $/ 3 \mathrm{ml}$. assay system) whilst the final concentration of tryptophane was $8.2 \times 10^{-4} \mathrm{M}$. $(0.5 \mathrm{mg} . / 3 \mathrm{ml}$. assay system). It was, however, noted that in all experiments, at zero and very low blood concentrations, the measured activity was greater without the nicotinamide and tryptophane. As it had been reported that nicotinamide in high concentration is inhibitory to 6-phosphogluconate dehydrogenase (Dickens and Glock, 1952), experiments were performed to determine the optimum concentration

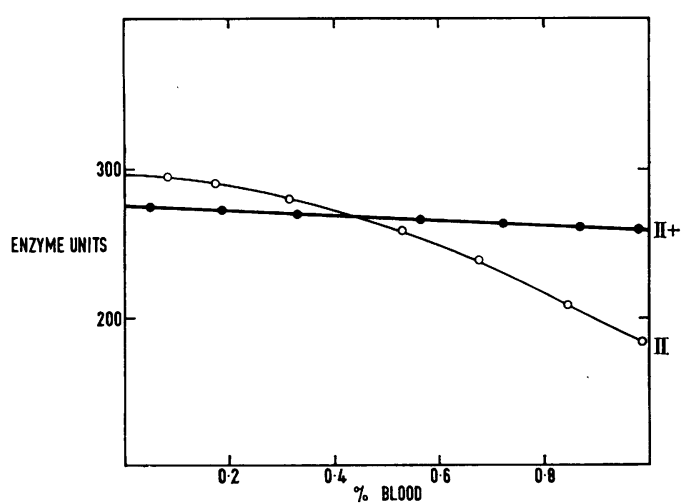

FIG. 2. 


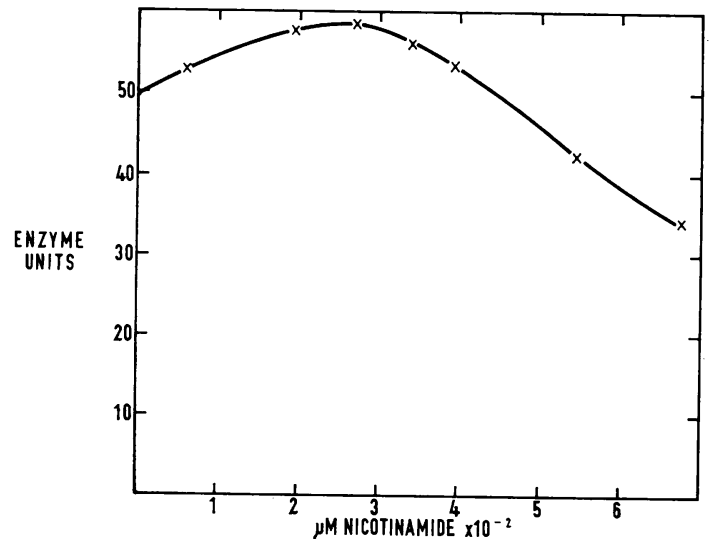

FIG. 3.

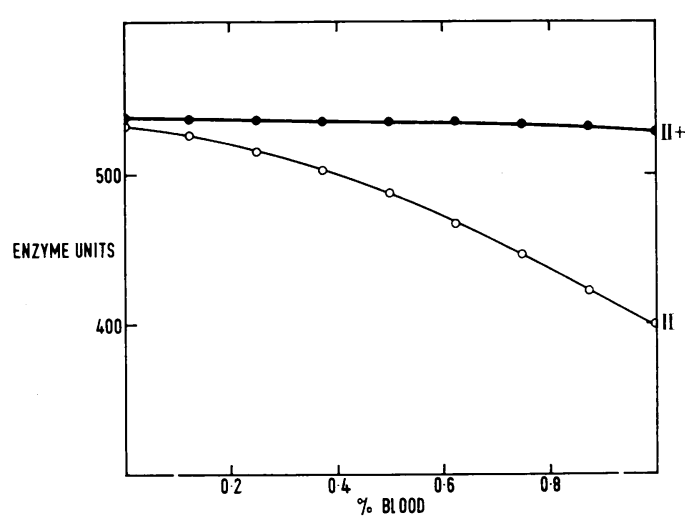

FIG. 4.

FIG. 3. Effect of nicotinamide concentration on vaginal fluid 6-phosphogluconate dehydrogenase.

FIG. 4. Effect of nicotinamide concentration on assay in the presence of blood. $\bigcirc-\bigcirc \quad$ System II alone System II assay and nicotinamide $2 \cdot 7 \times 10^{-2} \mathrm{M}$ and tryptophane $8.2 \times 10^{-4} \mathrm{M}$

of nicotinamide for use (Fig. 3). The result clearly indicated that the optimum concentration of nicotinamide was $2.7 \times 10^{-2} \mathrm{M}$. $(10 \mathrm{mg} / 3 \mathrm{ml}$ assay system) and when the previous experiments on the effect of blood were repeated using this concentration of nicotinamide, no inhibition of the 6-phosphogluconate dehydrogenase was found and a linear response unaffected by blood concentration with the range of 0 to $0.5 \%$ was demonstrated (Fig. 4).

\section{CONCLUSIONS}

It is clear that blood, even in very low concentrations, interferes with the assay of 6-phosphogluconate dehydrogenase, usually giving markedly lower results with the conventional assay method as described in system I. At the $1 \%$ level of blood up to $50 \%$ inhibition has been noted (Fig. 1).

Considerable improvement of the assay is obtained by coupling the reduced NADP to 2.6 dichlorophenol indophenol with phenazine methosulphate. The improvement may be due in part to the diminished oxidation of $\mathrm{NADPH}_{2}$ by atmospheric oxygen mediated by the haemoglobin present, but this assay system may be beneficial even in the absence of blood, for vaginal fluid specimens often have an oxidative activity with respect to the 6phosphogluconate 'dehydrogenase system. Certainly much of the apparent inhibition is caused by the nucleotidases present in the blood breaking down the $\mathrm{NADPH}_{2}$ at $p \mathrm{H} \mathrm{9.0.} \mathrm{This} \mathrm{has} \mathrm{been} \mathrm{overcome}$ by the addition of $10 \mathrm{mg}$ nicotinamide and $0.5 \mathrm{mg}$ tryptophane to the $3 \mathrm{ml}$. assay system giving a linear response unaffected by blood concentration within the range studied.

In view of widespread study of 6-phosphogluconate dehydrogenase as an enzyme screening procedure for cervical cancer, it is important to realize that contamination of the specimen by blood may be of critical importance. The modifications suggested here show that the inhibiting action of blood can be overcome by the inclusion of nicotinamide and tryptophane. A further improvement in the method has been obtained by the use of 2:6 dichlophenol indolephenol and phenazine methosulphate.

This work has been supported by the British Empire Cancer Campaign to which I am most grateful. I would like to thank Dr. T. F. Slater for his advice and criticism and Miss Margaret Snelling, who allowed me access to her patients at the Marie Curie Hospital; also I should like to thank Sister D. Pracy for her valuable assistance in collecting the vaginal fluid specimens.

\section{REFERENCES}

Bonham, D. G., and Gibbs, D. F. (1962). Brit. med. J., 2, 823.

Boyd, J. T., Gibbs, D. F., Labrum, A. H., and Philps, F. R. (1967). Ibid., 2, 785 .

Cameron, C. B. (1964). Proc. Technicon 25 Int. Symp., London.

Dickens, F., and Glock, G. E. (1952). Biochem. J., 50, 81.

Gibbs, D. F. (1968). To be published.

International Union of Biochemistry (1961). Report of the Commission on Enzymes (I.U.B. Symposium Ser., vol. 20, p. 10). Pergamon Press, New York.

Labrum, A. H. (1965). J. Obstet. Gynaec. Brit. Cwlth, 72, 138.

Lowry, O. H., Passonneau, J. V., and Rock, M. K. (1961). J. biol. Chem., 236, 2756.

Meijer, A. E. F. H. (1962). Clin. chim. Acta, 7, 638.

Nerdrum, H. J. (1964). Scand. J. clin. Lab. Invest., 16, 565. 